\title{
Protection against Children who Conflict with the Law Due to the Delinquency Reviewed from the Juvenile Criminal Jurisdiction System
}

\author{
Nia Yulianti ${ }^{1}$, Zudan Arief Fakrulloh ${ }^{2}$ \\ Doctoral of Law, Universitas Borobudur Jakarta \\ \{niaunbor@gmail.com¹, cclsis@yahoo.com²\}
}

\begin{abstract}
The Constitution guarantees every child to live, grow and develop and has the right to protection from violence and discrimination. Therefore, Indonesia as a rule of law has the obligation and responsibility to provide protection, one of which is for children who conflict with the law. A child in conflict with the law is a child who is 12 (twelve) years old, but not yet 18 (eighteen) years old, who is suspected of having committed a criminal act. One of the causes of conflict with the law is child delinquency. Many can factor cause delinquency in children. According to Law Number 11 of 2012 concerning the Criminal Justice System for Children, cases of children in conflict with the law must be adjudicated in juvenile criminal courts located within the general court. However, before entering the judicial process, law enforcers, families, and the community are obliged to seek a settlement process outside the court, namely through Diversion based on the Restorative Justice approach. The objective of juvenile justice is not merely to prioritize the crime as the main element, but protection for the future of the child is a goal that juvenile justice aims to achieve. Therefore, the imposition of punishment must have attempted as a last option after all means are considered inadequate (ultimum remidium).
\end{abstract}

Keywords: Protection; Children Who Conflicted With Law; Children Delinquency

\section{Introduction}

Children are an inseparable part of the sustainability of human life and the sustainability of a nation and state. In the 1945 Constitution of the Republic of Indonesia, Article 28B, children have a strategic role which explicitly states that "The state guarantees every child to live, grow and develop and is entitled to protection from violence and discrimination". This provision is a form of state protection for children.

Law Number 39 of 1999 concerning Human Rights, Article 52 and Article 66, states that children's civil, political and cultural rights need to be respected and protected. The realization of state guarantees for child protection is mainly through the existence of Law Number 23 of 
2002 concerning Child Protection which was later amended to Law Number 35 of 2014 concerning Amendments to Law Number 23 of 2002 concerning Child Protection.

In Law Number 23 of 2002 concerning Child Protection, Article 59 states that the government and other state institutions are obliged and responsible for providing special protection, one of which is for children in conflict with the law. Apart from that is Law Number 11 of 2012 concerning the Juvenile Criminal Justice System. If you look at the background of the birth of this law as stated in its preamble which states that children are a mandate and a gift from God Almighty who has dignity as a whole human being and to protect their dignity, children have the right to special protection, especially legal protection in the judicial system, then, in fact, we want to realize better handling of cases of children involved in criminal acts than before.

The birth of this law is the first reference for the judiciary of children in conflict with the law, one of which is the result of delinquency, this law is intended to improve child criminal law in Indonesia so that juvenile court decisions become better and more qualified because the judge's decision will affect the child's life in the future. The existence of Law Number 11 of 2012 concerning the Juvenile Criminal Justice System more clearly means that this law is formal or procedural in the juvenile criminal justice process in conflict with the law suspected of committing a criminal act so that in processing children as perpetrators criminal law no longer refers to the Criminal Code.

The existence of legal rules regulating the protection of children's rights, and the existence of an institution or agency whose duties and functions are to protect children's rights, show that legal protection by the state for children is adequate. This rule of law is to minimize cases of children in conflict with the law. However, this has not been able to suppress the increase in the quantity and quality of cases involving children both as victims and in conflict with the law. The term conflict with the law refers to Law Number 11 of 2012 concerning the Criminal Justice System for Children, Article 1 point 3, states that "Children in conflict with the law, hereinafter referred to as Children, are children who have reached the age of 12 (twelve) years, but have not 18 (eighteen) years old who is suspected of having committed a criminal act".

The entry of a child into the classification of the perpetrator of a criminal act, where criminal cases involving children as perpetrators of crimes carry a separate phenomenon. Considering that children are individuals who are still emotionally unstable and have become legal subjects, then the treatment of criminal cases with child offenders needs special attention, starting from the criminal procedure law that applies to children. The juvenile criminal justice system specifically regulates the obligations and rights that children receive.

In connection with this, in daily life, there are frequent problems of children in conflict with the law caused by children's delinquency, especially children over the age of 12 to 18 years. Children in conflict with the law are always increasing every year, if one looks at the development of children in conflict with the law, which is categorized as a crime committed by children so far, both in terms of quality and modus operandi, sometimes the violations committed by these children are felt. has troubled all parties, especially parents. The phenomenon of increasing deviant behavior in the form of crimes committed due to children's delinquency does not seem to be proportional to the age of the perpetrator.

Starting from the problems related to legal protection that must be given to a child in conflict with the law, of course, there must be efforts from various parties to save him. Therefore, the issue of child legal protection in conflict with the law is important to be studied and discussed according to the juvenile criminal justice system. 


\section{Research Problem}

Based on the background described above, the formulation of this research problem can be formulated as follows: How is the protection for children who conflict with the law due to delinquency according to the juvenile criminal justice system?

\section{Methodology}

This research is normative legal research. Normative research is often called doctrinal research, which is research whose object of study is legal documents and library materials [1]. The approach used is the statute approach and the conceptual approach [2]. Also, it uses a sociological juridical approach.

\section{Result and Discussion}

The definition of "child" in the eyes of positive law in Indonesia is generally defined as a person who is not yet mature (minderjaring or person under age), a person who is underage or underage conditions (minderjaringheid or inferiority) or often referred to as a child under the supervision of a guardian. (minderjarige onvervoodij) [3].

According to Paulus Hadisuprapto, at the international level, it seems that there is no uniformity in the formulation of boundaries regarding children, the age level of a person is categorized as a child between one country and another, which is quite diverse, namely [4]: "Twenty-seven countries in the United States determine age limits between 8-17 years old, other states determine the age limit between 8-16. In England, the age limit is set between 1216 years. Australia, in most countries, has an age limit of 8-16 years. The Netherlands determines bricks aged between 12-18 years. Asian countries among other things: Sri Lanka sets the age limit between 8-16 years, Iran 6-18 years, Japan and Korea determine the age limit between 14-18 years, Cambodia sets the age limit between 15-18 years, while ASEAN countries, among others, the Philippines determine the age limit between 7-16 years."

Based on the explanation above, it turns out that Indonesia's positive law (ius constitutum) does not regulate the existence of a standardized and universally applicable legal unification to determine the age limit criteria for a child. There are various kinds of opinions regarding the meaning of children, and at what age, a person is categorized as a child. The meaning of children can be seen in the formulation of various laws and regulations with limitations that can differ from one another. According to the Convention on the Right of the Child on November 20, 1989, which has been ratified by Indonesia, it is stated in Article 1 that the definition of a child is "All persons under the age of 18 years. Unless the law stipulates maturity is reached earlier".

The Beijing Rules, Article 2.2 letter (a) states "A child is a child or young person who according to the respective legal system can be treated for an offense of law in a way different from that of an adult". According to the Criminal Code (KUHP), the definition of a child is regulated in the provisions of Articles 45, 46, and 47 of the Criminal Code which only signifies the age limit before the age of 16 (sixteen) years for people who are not old enough (minderjarig). These articles have been revoked and declared invalid with the issuance of Law Number 3 of 1997 concerning Juvenile Court. 
According to Law Number 3 of 1997 concerning Juvenile Court, Article 1, what is meant by a child is a person who has reached the age of 8 (eight) years but has not reached the age of 18 (eighteen) years and has never been married. Meanwhile, according to Law Number 39 of 1999 concerning Human Rights, Article 1 point 5, that a child is every human being under 18 years of age and is not married, including children who are still in the womb if it is in his interest. Law No. 13 of 2003 concerning Manpower, which confirms that a child is anyone under 18 (eighteen) years of age.

Furthermore, according to Law Number 11 of 2012 concerning the Criminal Justice System for Children, Article 1 point 3, which is referred to as children who have reached 12 (twelve) years of age but are not yet 18 (eighteen) years old. According to Law Number 35 of 2014 concerning Child Protection, Article 1 paragraph (1), that a child is someone who is not yet 18 (eighteen) years old, including the unborn children. The various criteria for a child's age limit are the grouping of the maximum age as a manifestation of the ability of a child in legal status so that the child will change the status to adulthood or become a legal subject whose data is independently responsible for the actions and legal actions taken by that kid [5].

There are 3 phases in a child's development, namely, the first phase is starting from 0-7 years, namely childhood and the growth period for children's growth. The second phase of children starts from 7-14 years, namely when the child enters a community outside the family, namely school, the child socializes directly with friends and the community. This phase is also the pre-puberty period where physical functions are mature and tends to act somewhat harshly and impolite. While the 3rd phase is the most important where from the age of 14-21 years which is called adolescence, this period is a period of liaison and a period of transition into adulthood. It is precisely at this time that is very vulnerable for adolescents because this time there are major changes that have an impact on attitudes toward more aggressive actions and actions and these actions are leading to juvenile delinquency symptoms [6]. That the period when children are said to be adolescents is a very striking development phase both physically, psychologically, socially, and morally, adolescence period, aged 13-21 years the child is experiencing a mental shock [7].

Most of the children do illegal acts, from actions that were initially limited to juvenile delinquency which eventually led to criminal acts that require serious legal handling [8]. Actions that conflict with the law committed by children generally come from delinquent behavior of children. The term delinquency comes from delinquency, which is defined as child delinquency, juvenile delinquency, youth delinquency, and delinquency. The word delinquency or delinquency is found together with the word juvenile, because delinquency is closely related to children, whereas the word delinquency act is defined as an act that violates the basic norms of society. When this action is done by a group of children, it is called delinquency [9].

According to Anthony M. Platt, the definition of delinquency is a child's act which includes (1) a criminal act if it is committed by an adult, (2) an act that violates the rules of the state or society, (3) violent immoral behavior, truancy, rude words indecent, growing up on the streets and associating with bad people who may be a bad influence on the child in the future [10]. According to Romli Atmasasmita, the term delinquency is not synonymous with the term delinquency and the term juvenile is not synonymous with the term child. The term juvenile delinquency has a broader meaning than the term delinquency or children terms. Therefore, Romli tends to use the term child delinquency more than the term juvenile crime. [11] The delinquency of the child is a manifestation of youthfulness so that he is faced with the law, but without any intention of harming others as implied in a crime listed in the 
Criminal Code (KUHP) where the perpetrator must be aware of the consequences of his actions, and the perpetrator is responsible for his actions.

The factors causing the occurrence of children in conflict with the law are generally due to the expectation gap or the absence of a match between the ideals and the means that can support the achievement of these goals. The factors that cause a child to come into conflict with the law include:

a. Motivation Factors. Children who commit acts of delinquency or conflict with the law are generally motivated to seek attention by violating social and legal norms.

b. Economic factors. The economic condition of the perpetrator of the crime of theft is someone committing the crime of theft. This is because of the pressing economic pressure and because it is to make ends meet.

c. Family Factors. According to Moelyatno, broken homes cause most children to commit delinquency, especially due to divorce or parental separation which greatly affects the development of the child's growth and in the broken home itself some things cause the family to be incomplete, including: [12] 1) One of the parents of the child or even both have died 2) Divorce from the parents 3) One of the parents was not present continuously for a long time.

d. Educational factors. Education also affects the occurrence of children committing the crime of theft, where the education level of the offender is on average only completing elementary school or dropping out of high school.

e. Environmental factors. The good and bad behavior of a child is greatly influenced by the environment in which the person is located, the association followed by the imitation of an environment will greatly affect a person's personality and behavior, so that because of the child's delinquency the courage to commit a crime The environment in question includes the family environment and the surrounding atmosphere

\section{Children Protection}

In terms of international law, legal instruments regulating the protection of children's rights are regulated in the 1989 UN Convention on the Rights of the Child and have been ratified by 191 countries. The Indonesian has ratified it with Presidential Decree No. 36 of 1990. Thus, the UN Convention on the Rights of the Child has become Indonesian law and binds all Indonesian citizens. The Convention on the Rights of the Child is a legal instrument that contains the formulation of universal principles and provisions of legal norms regarding children. The Convention on the Rights of the Child is an international treaty on human rights which includes civil and political rights, economic, social, and cultural rights, respectively.

It is also explained in Law Number 35 of 2014 concerning Child Protection, Article 1 paragraph (2) that "child protection is all activities to guarantee and protect children and their rights so that they can live, grow, develop and participate optimally following dignity, and human dignity, and receive protection from violence and discrimination".

Based on this provision, that every child has the right to obtain freedom and legal protection. The arrest, detention, or punishment of a child is only carried out according to the applicable law it can only be done as a last resort. Child legal protection is an attempt to protect the law against various freedoms and children's rights [13]. Law Number 11 of 2012 concerning the Criminal Justice System for Children, Article 1 paragraph (3), states "Children who conflict with the law, hereinafter referred to as Children, are children who have reached the age of 12 (twelve) years, but are not yet 18 (eighteen) years that are suspected of committing a criminal act". 
This Law on Juvenile Criminal Justice System regulates the entire process of resolving cases of children in conflict with the law from the investigation stage to the guidance stage after serving a crime. In Law Number 11 of 2012 concerning the Criminal Justice System for Children, Article 2 states that the Juvenile Criminal Justice System is implemented based on the principles of: a. protection; b. justice; c. non-discrimination; d. best interests of the child; e. respect for children's opinions; f. child survival and development; g. coaching and mentoring of children; h. proportional; i. deprivation of liberty and punishment as a last resort; and $\mathrm{J}$. retaliation avoidance.

Article 3 of the same law states, every child in the criminal justice process has the right, among others: a. Treated humanely with attention to the needs according to age; $b$. Separated from adults; c. Performing recreational activities; d. Free from torture, punishment, or other cruel, inhuman, and degrading treatment of dignity and status; e. Not sentenced to death or life imprisonment; and f. Not arrested, detained, or imprisoned, except as a last resort and for the shortest time.

Reminding the features and characteristics that are unique to children and for the protection of children, cases of children in conflict with the law must be tried in juvenile court in the general court environment. Since juvenile justice processes are arrested, detained, and tried, their guidance must be carried out by special officials who understand the problems of children. However, before starting the judicial process, law enforcers, families, and the community are required to seek a settlement process outside the court route, namely through Diversion based on the Restorative Justice approach.

According to John Braithwaite, restorative justice is a process that involves all parties who have an interest in certain violations to come together to resolve collectively how to respond to and resolve the consequences of violations and their implications for the future [14]. Marian Liebmann in simpler language, said that "restorative justice is a legal system that aims to restore the welfare of victims, perpetrators, and communities damaged by crime, and to prevent further violations or crimes" [15]. Through the concept of restorative justice, it is hoped that it can fulfill the balance of rights between perpetrators of criminal acts, victims of criminal acts, and the community as a community whose social system is disturbed.

Restorative justice is the settlement of criminal cases involving perpetrators, victims, families of perpetrators/victims, and other related parties to jointly seek a fair settlement by emphasizing restoration to its original state, and not retaliation, [16] which includes criminal investigation and prosecution of children carried out under the provisions of laws and regulations unless otherwise stipulated in this Law; Juvenile trials conducted by courts within the general court; and guidance, guidance, supervision and/or assistance during the process of committing a crime or action and after undergoing a crime or action [17].

Meanwhile, diversion is the transfer of settlement of juvenile cases from the criminal justice process to non-criminal justice processes, [18] which aims to achieve peace between the victim and the child; resolving cases of children outside the judicial process; resolving cases of children outside the judicial process; prevent children from being deprived of liberty; encourage the community to participate, and instill a sense of responsibility in children [19]. The purpose of the diversion is following Law Number 35 of 2014 concerning Child Protection, Article 64, namely Special Protection for Children in conflict with the law through:

a. Humane treatment with attention to the needs according to age;

b. Separation from adults;

c. Providing legal assistance and other assistance effectively;

d. Enforcement of recreational activities; 
e. Exemption from torture, punishment or other cruel, inhuman, and degrading treatment of dignity and degree;

f. Avoidance of death penalty and/or life imprisonment;

g. Avoidance of arrest, detention, or imprisonment, except as a last resort and for the shortest time;

h. Providing justice before the juvenile court that is objective, impartial, and in sessions that are closed to the public;

i. Avoidance of publication of his identity.

j. Providing assistance to parents / guardians and people trusted by the child;

k. Providing social advocacy;

1. Giving of personal life;

m. Providing accessibility, especially for children with disabilities;

n. Education provision;

o. Provision of health services; and

p. Granting other rights under the provisions of laws and regulations.

In contrast to efforts to overcome criminal acts through penal or criminal law, it focuses more on repressive characteristics, namely in the form of eradication or suppression after a crime has occurred. The term juvenile justice system is a translation of the term The Juvenile Justice System, which is a term that can be used by several institutions that are members of the court, including the police, public prosecutors, and legal advisors, as well as supervisory agencies, child detention centers, and finally, are child development facilities [20].

According to Maidin Gultom, juvenile criminal justice is basically to make corrections, rehabilitation not punishment, that sooner or later, children can return to normal community life and not end their hopes and future potential. Imposing a crime or action is an action that must be accounted for and can benefit the child. Every execution of a crime or action shall be attempted not to cause victim, suffering, mental, physical, and social harm. To prevent undesirable consequences that are detrimental in nature, it is necessary to pay attention to the ethical basis for the punishment, namely justice as the only basis for punishment, every act of punishment is judged not only based on the nature of justice but also on the nature of harmony it will achieve, because it is in harmony.

Justice is also reflected, punishment is an act against a naughty child who can be held accountable for his actions, the judgment of a delinquent child is not always based on the quality of his spiritual and psychological abilities at the time the delinquency is committed, but mainly based on their ability to receive punishment and actions [21]. Based on the explanation above, it can be seen that the purpose of juvenile justice is not merely to prioritize the crime as the main element, but rather that protection for the future of the child is the goal that juvenile justice aims to achieve. If there is a criminal sanction for a child who is imposed, but still it must be with the best consideration for the child and not an attempt to retaliate, so that the imposition of punishment must be attempted as a last resort after all means are deemed inadequate (ultimum remidium).

\section{Conclusion and Suggestion}

\subsection{Conclusion}

Indonesia is a country of law. As a rule of law, it is obliged to guarantee every child to live, grow and develop and have the right to protection from violence and discrimination. 
Besides, the state has the obligation and responsibility to protect children in conflict with the law. The occurrence of conflicts with the law is the result of children's delinquency. Various factors cause children's delinquency, including motivational, economic, family, educational and environmental factors. In resolving cases of children in conflict, there are efforts to resolve cases outside the court, namely through diversion based on the Restorative Justice approach, which involves perpetrators, victims, families of perpetrators/victims, and other related parties to collectively seek a fair settlement by emphasizing recovery back to its original state, and not retaliation.

\subsection{Suggestion}

The importance of effective socialization among the main community among law enforcers and stakeholders regarding Law Number 11 of 2012 concerning the Juvenile Criminal Justice System. This is intended so that law enforcers and stakeholders know that the purpose of juvenile justice is not just to prioritize the crime as the main element, but that protection for the future of the child is the goal that the juvenile justice system is trying to achieve. Besides, it is expected that criminal penalties must be pursued as a last resort after all methods are considered inadequate (ultimum remidium).

\section{References}

[1] Soejono dan H. Abdurahman.: Metode Penelitian Hukum. Rineka Cipta Jakarta (2003).

[2] Marzuki, Peter Mahmud.: Penelitian Hukum. Edisi Revisi. Prenada Kencana, Jakarta (2014).

[3] Mulyadi, Lilik.: Pengadilan Anak di Indoneia. Teori, Praktek dan Permasalahannya. Mandar Maju, Bandung (2005).

[4] Hadisuprapto, Paulus.: Juvenile Delinquency, Pemahaman dan Penanggulangannya. Citra Aditya Bakti, Bandung (1997).

[5] Wadong, Maulana Hasan.: Advokasi dan Hukum Perlindungan Anak. Garsindo, Jakarta (2000).

[6] Soetodjo, Wagiati.: Hukum Pidana Anak. Refika Aditama, Bandung (2006).

[7] Sudarsono.: Kenakalan Remaja. Rineka Cipta, Jakarta (1991).

[8] Sudarto.: Hukum Pidana dan Perkembangan Masyarakat. Sinar Baru, Bandung (1983).

[9] Marlina.: Peradilan Pidana Anak di Indonesia Pengembangan Konsep Diversi dan Restorative Justice. Aditama, Medan (2012).

[10] Platt, Anthony M.: The Child Savers: The Invention of Delinquency. Second Edition, The University of Chicago Press, Chicago (1977).

[11] Atmasasmita, Romli.: Problem Kenakalan Anak-Anak/Remaja. Armico, Jakarta (1983).

[12] Soetodjo, Wagiati.: Hukum Pidana Anak. Refika Aditama, Bandung (2006).

[13] Arif, Barda Nawawi.: Beberapa Aspek Kebijaksanaan Penegakan dan Pengembangan Hukum Pidana. PT Citra Aditya Bakti, Bandung (1998).

[14] Braitwaite, John.: Restorative Justice and Responsive Regulation. London: Oxford University Press (2002).

[15] Liebmann, Marian.: Restorative Justice: How it Works. London and Philadelphia: Jessica Kingsley Publishers (2007). 
[16] Undang-Undang Republik Indonesia Nomor 11 Tahun 2012 tentang Sistem Peradilan Pidana Anak.

[17] Undang-Undang Republik Indonesia Nomor 11 Tahun 2012 tentang Sistem Peradilan Pidana Anak.

[18] Undang-Undang Republik Indonesia Nomor 11 Tahun 2012 tentang Sistem Peradilan Pidana Anak.

[19] Undang-Undang Republik Indonesia Nomor 11 Tahun 2012 tentang Sistem Peradilan Pidana Anak.

[20] Mc Cord, Joan, Cathy Spatz Widom, and Nancy A. Crowell, eds.: Juvenile Crime, Juvenile Justice, Panel on Juvenile Crime: Prevention, Treatment, and Control. National Academy Press, Washington DC (2001).

[21] Gultom, Maidin.: Perlindungan Anak dalam Sistem Peradilan Pidana Anak di Indonesia. Refika Aditama, Cetakan I. Bandung (2008). 